University of Wollongong

Research Online

Faculty of Engineering - Papers (Archive)

Faculty of Engineering and Information

Sciences

$1-1-2012$

\title{
Strength development in blended cement admixed saline clay
}

Suksun Horpibulsuk

Suranaree University of Technology, suksun@g.sut.ac.th

Worawit Phojan

Suranaree University of Technology

Apichat Suddeepong

Suranaree University of Technology

Avirut Chinkulkijniwat

Suranaree University of Technology

Martin D. Liu

University of Wollongong, martindl@uow.edu.au

Follow this and additional works at: https://ro.uow.edu.au/engpapers

Part of the Engineering Commons

https://ro.uow.edu.au/engpapers/5298

\section{Recommended Citation}

Horpibulsuk, Suksun; Phojan, Worawit; Suddeepong, Apichat; Chinkulkijniwat, Avirut; and Liu, Martin D.:

Strength development in blended cement admixed saline clay 2012, 44-52.

https://ro.uow.edu.au/engpapers/5298

Research Online is the open access institutional repository for the University of Wollongong. For further information contact the UOW Library: research-pubs@uow.edu.au 


\title{
STRENGTH DEVELOPMENT IN BLENDED CEMENT ADMIXED SALINE CLAY
}

\author{
Suksun Horpibulsuk, B.Eng.(Hons), M.Eng., Ph.D.
}

Professor and Chair of School of Civil Engineering, Suranaree University of Technology, 111 University Avenue, Muang District, Nakhon Ratchasima 30000, THAILAND

Tel: +66-44-22-4322 and +66-89-767-5759, Fax: +66-44-22-4607

Email: suksun@g.sut.ac.th and suksun@yahoo.com

Avirut Chinkulkijniwat, B.Eng. (Hons), M.Eng., D.Eng. Assistant Professor, School of Civil Engineering,

Suranaree University of Technology, 111 University Avenue, Muang District, Nakhon Ratchasima 30000 THAILAND

Worawit Phojan, B.Eng., M.Eng.

School of Civil Engineering, Suranaree University of Technology, 111 University Avenue, Muang District, Nakhon Ratchasima 30000, THAILAND

Martin D. Liu, B.Eng., M.Phl., Ph.D. Senior Lecturer, Faculty of Engineering University of Wollongong NSW 2522, Australia

Tel: + 612 4221-3035; Fax: + 612 4221-3238 martindl@uow.edu.au

Date written: 4 February 2011 Number of words:

NOTE: The first author is the correspondence author. Mail communication may please be addressed to Prof. Suksun Horpibulsuk, School of Civil Engineering, Suranaree University of Technology, 111 University Avenue, Muang District, Nakhon-Ratchasima 30000, THAILAND 


\title{
STRENGTH DEVELOPMENT IN BLENDED CEMENT ADMIXED SALINE CLAY
}

\author{
Suksun Horpibulsuk ${ }^{1}$, Voravit Phochan ${ }^{2}$, Avirut Chinkulkijniwat ${ }^{3}$, and Martin D. Liu ${ }^{4}$
}

Abstract: Cement stabilization is extensively used to improve engineering properties of soft saline clay. The effect of salinity, which is altered with geological and climate changes, on the strength development in cement admixed saline clay is investigated in this paper. For a particular curing time and salt content, the strength development in cement admixed saline clay is governed by the clay-water/cement ratio, $w_{c} / C$. The strength increases with the decrease in $w_{c} / C$. The increase in salt content for a particular water content causes the increase in generalized stress state, $e / e_{L}$ where $e$ is the current void ratio and $e_{L}$ is the liquid limit void ratio. The higher value of $e / e_{L}$ is associated with the lower effective stress and the interparticle attraction. Hence, for the same clay-water/cement ratio, the strength of the cement admixed clay with higher salt content is lower than that with lower salt content. From the strength, economic, and environmental points of view, waste ashes (fly ash and biomass ash) can be used to substitute Portland cement. The role of ashes on the strength development of cement admixed saline clay is investigated via unconfined compressive (UC) test and thermogravimetric (TG) analysis. Fly ash and biomass ash are dispersing materials, increasing the reactive surface of the cement grains, and hence strength increases. The clay-water/cement ratio hypothesis is successfully used to analyze and assess the strength development of blended cement admixed saline clay at various salt contents. An addition of $25 \%$ ash can save on the input of cement up to $15.8 \%$.

\footnotetext{
${ }^{1}$ Professor and Chair, School of Civil Engineering, Suranaree University of Technology, Nakhon Ratchasima, Thailand, suksun@g.sut.ac.th

${ }^{2}$ M.Eng. Graduate, ditto

${ }^{3}$ Assistant Professor, ditto

${ }^{4}$ Senior Lecturer, Faculty of Engineering, The University of Wollongong, AUSTRALIA
} 
66

67 Keywords: saline clay, blended cement, clay-water/cement ratio, unconfined compressive 68 strength

69

70

71

72

73

74

75

76

77

78

79

80

81

82

83

84

85

86

87

88

89

90 


\section{INTRODUCTION}

Northeast Thailand covers more than one-third of the country of 16.9 million ha with

9.25 million ha of agricultural land or $44 \%$ of the arable land in the country. There is about

2.8 million ha of saline soil or $17 \%$ of the total area in northeast Thailand. The soils are classified as severe, moderate and slight areas of 240,000, 590,000 and 2,020,000 ha, respectively (Yuvaniyama et al., 2005). The surface salinity originates from the rock salt beads of the Mahasarakam Formation of the Mesozoic Khorat Group. For wet lands, flood

plains and lowlands, the saline soil is generally saturated and soft clay deposits. Its salinity is changed with time due to climate and geological changes. This soft saline clay possesses high compressibility and low shear strength. One of the extensively used soil improvement techniques is the in-situ cement stabilization such as shallow and deep mixing. This technique is economical because cement is readily available at reasonable cost in Thailand. Moreover, adequate strength can be achieved in a short time.

The fundamental mechanical characteristics of cement admixed clays have been experimentally and numerically investigated by many researchers (Terashi, 1979; Kawasaki et al., 1981; Kamon and Bergado, 1992; Horpibulsuk et al., 2004a and b and 2010a; and Suebsuk et al., 2010 and 2011). These investigations mainly focused on the influence of water content and cement content. The combination effect from both water content and cement

110 content is integrated by the clay-water/cement ratio (Horpibulsuk and Miura, 2001;

111 Horpibulsuk et al., 2005; and Miura et al., 2001). The clay-water/cement ratio, $w_{c} / C$ is defined

112 as the ratio of clay water content to cement content (both reckoned in percentage). While the

113 clay water content reflects the microfabric of soft clay, the cement content influences the level

114 of bonding of that fabric. Based on this parameter and Abrams' law (Abrams' 1918), 115 Horpibulsuk et al. (2003) introduced a phenomenological model for predicting laboratory 
116 strength development in cement admixed clays at various water contents, cement contents and

117 curing times. This model was refined to develop a generalized strength equation for cement

118 admixed non- to low swelling clays (Horpibulsuk et al., 2011b).

119 For engineering, economic and environmental impacts, the replacement of the cement

120 by waste materials such as fly ash and biomass ash is highly attractive and valuable. In

121 Thailand, the generation of these waste materials is general far in excess of their utilization. A

122 feasibility study of utilizing these ashes (waste materials) to partially replace Type I Portland

123 cement is thus significant. The role of fly ash on the strength development in the blended

124 cement admixed clay was investigated both from macro- and micro-observations

125 (Horpibulsuk et al., 2009; and Horpibulsuk and Raksachon, 2010). Unlike in concrete (with

126 required 28-day strength generally higher than $28 \mathrm{MPa}$ ), fly ash in cement admixed clays

127 (required 28-day strength only 600-3000 kPa) does not act as the pozzolanic material because

128 of the low $\mathrm{Ca}(\mathrm{OH})_{2}$ from hydration to be reactive with. When the soft clay is mixed with

129 cement, the clay and cement particles group together into large clay-cement clusters due to

130 physicochemical interaction (Horpibulsuk et al., 2010b). Fly ash disperses large clay-cement

131 clusters into smaller clusters. The dispersion leads to the increase in the reactive surface, and

132 hence strength enhancement. Particle size of the fly ash influences insignificantly the

133 dispersing effect.

134 The dispersing effect can be regarded akin as an addition of cement. By considering

135 that the ash content can be equivalent to cement content, the clay-water/cement ratio

136 hypothesis for blended cement admixed clay (Horpibulsuk et al., 2011a) was developed as

137 follows: "For given set of blended cement admixed clay samples, the strength development

138 depends only on the clay-water/cement ratio, $w_{c} / C$, where the total cement content $(C)$ is the

139 sum of input of cement $\left(C_{i}\right)$ and equivalent cement content $\left(C_{e}\right)$ )". The equivalent cement

140 content $\left(C_{e}\right)$ is equal to $k a$ where $k$ is dispersing factor and $a$ is ash content. Because the 
141 pozzolanic reaction is minimal, the $C_{e}$ is mainly dependent upon the dispersing effect,

142 governing by the ash content and alters insignificantly with curing time. In other words, the $k$ -

143 value is practically constant with curing time for a given combination of cement content and

144 ash content. The thermogravimetric (TG) analysis showed that the cementitious products of

145 the blended cement admixed clay samples are practically the same as long as the $w_{c} / C$ is the

146 same. Based on the Abrams' law and the clay-water/cement ratio hypothesis for blended

147 cement admixed clay, the strength equation was proposed:

148

$q_{u}=\frac{A}{\left(\frac{w_{c}}{C_{i}(1+k a)}\right)^{B}}$

where $q_{u}$ is the compressive strength of blended cement admixed clay at a specific curing time, $w_{c}$ is clay water content, $A$ and $B$ are empirical constants. The three parameters $A, B$ and $k$ for different curing times can be determined from a multi-regression analysis (MRA). The $A$-value increases with curing time and is mainly dependent upon the clay type. For non- to

153 low-swelling clays, the $B$-value is almost constant, being equal to 1.27 . The $k$-value is 154 independent of curing time and ash type. It is about 0.75 for blended cement admixed 155 Bangkok clay. When $a=0 \%$ (no ash), Eq.(1) becomes that developed for the cement admixed 156 clays (without ash) by Horpibulsuk et al. (2011b).

Even with available literature on engineering properties of cement admixed clays, the 158 investigation of the effect of salinity on the engineering properties is very limited. The change 159 in the pore water chemistry, caused by the salinity change, leads to a modification of the basic 160 clay-water interaction and affects both the physical and engineering properties of remolded 161 clay. Horpibulsuk et al. (2011c) showed that the generalized stress state, $e / e_{L}$ (where $e$ is void 162 ratio and $e_{L}$ is liquid limit void ratio) is a useful parameter to interpret the intrinsic 163 engineering properties when their pore medium chemistry is changed. As the $e / e_{L}$ decreases, 164 both effective stress and shear resistance of the remolded clays increase. 

of saline clay to explain strength development in cement admixed saline clay. The possibility

167 of using the clay-water/cement ratio hypothesis to analyze the strength development in 168 blended cement admixed saline clay is examined. The empirical constants $B$ and $k$ for 169 different salt contents are investigated. The $B$-and $k$-values obtained from the present work 170 and previous works (Horpibulsuk et al., 2003; 2011a and b) are analyzed to develop a 171 generalized strength equation for different blended cement admixed clays. Two blended 172 cements were used in this study, which are the fly ash blended cement and the biomass ash 173 blended cement. The role of the ashes on the cementitious products and the strength 174 development is illustrated by the thermogravimetric analysis and unconfined compression 175 test. This study and the generalized strength equation can be fundamental for analyzing and assessing the strength development in the other blended cement admixed clays.

\section{LABORATORY INVESTIGATION}

\subsection{Soil Sample}

Soil sample was collected from Phimai district, Nakhon Ratchasima, Thailand at a 2 meter depth. Phimai clay is saline alluvium that sits over residuum derived from the grained sedimentary rock. Phimai clay is classified into Typic Natraqualfs subgroup according to soil taxonomy. The soil sample is composed of $17 \%$ sand, $45 \%$ silt and $38 \%$ clay. Its specific

184 gravity is 2.65. The liquid and plastic limits are in the order of 43 and 24 percent, 185 respectively. Groundwater was at about $1 \mathrm{~m}$ below the ground surface. Natural water content was 39 percent, which is close to liquid limit. Based on the Unified Soil Classification System

187 (USCS), the clay is classified as low plasticity (CL). The free swell test proposed by Prakash and Sridharan (2004) showed that the clay is classified as low-swelling type with free swell ratio (FSR) of 1.3. The FSR is defined as the ratio of equilibrium sediment volume of $10 \mathrm{~g}$ of 
190 oven-dried soil passing a $425 \mathrm{~mm}$ sieve in distilled water $\left(V_{d}\right)$ to that in kerosene $\left(V_{k}\right)$. This 191 method was employed because it is simple and predicts dominant clay mineralogy of soils 192 satisfactory (Horpibulsuk et al., 2007). Chemical composition and grain size distribution 193 curve of the clay are shown in Table 1 and Figure 1, respectively. The SEM photo of the 194 saline clay is shown in Figure 2. This clay has electrical conductivity, $\mathrm{EC}_{\mathrm{e}}$ of $26 \mathrm{dS} / \mathrm{m}$, 195 sodium adsorption ratio, SAR of 3.34. With very high $\mathrm{EC}_{\mathrm{e}}$ (higher than 15 ), this soil is 196 classified as very strongly saline and dispersive (US Salinity Laboratory Staff, 1995).

197

198 Figure 1: Grain size distribution curves of Bangkok clay, PC, FA, and BA.

199 Figure 2: SEM photos of saline clay, PC, FA, BA.

200 Table 1: Chemical composition of saline clay.

201

202

203

\subsection{Cement, Fly Ash, and Biomass Ash}

204

Type I Portland cement (PC), fly ash (FA) from Mae Moh power plant in the north of 205 Thailand and biomass ash (BA) from Thai Power Supply Company Limited in Chachoengsao 206 province were used in this study. Chemical composition obtained from X-Ray Fluorescence 207 (XRF) analysis of PC, FA and BA is given in Table 2. Both FA and BA were passed through 208 sieve No. 325 to remove larger particles. Total amount of the major components $\mathrm{SiO}_{2}, \mathrm{Al}_{2} \mathrm{O}_{3}$ 209 and $\mathrm{Fe}_{2} \mathrm{O}_{3}$ in FA and BA are $79.44 \%$ and $75.57 \%$, respectively. FA is classified as class F fly 210 ash in accordance with ASTM C 618 whereas BA is referred to as "off-specification" because 211 it meets neither the class C nor class F criteria. Grain size distribution curves of PC, FA, and 212 BA are also shown in Figure 1. These curves were obtained from the laser particle size 213 analysis. Specific gravities of PC, FA and BA are 3.15, 2.54, and 1.95, respectively. SEM 
214 photos of PC, FA and BA are also shown in Figure 2. The PC and BA particles are irregular

215 in shape whereas the FA particles are spherical.

216

217 Table 2: Chemical composition of PC, FA and BA.

\subsection{Methodology}

The saline clay was passed through a 2-mm sieve to remove coarser particles. The clay was submerged for a week to dissolve the salinity and was mixed with salt to attain salt contents of $0.075,1.3,3,5,10$ and $15 \%$ dry weight of clay. The salt was obtained from a salt field in Phimai area. Its composition is shown in Table 3. $\mathrm{NaCl}$ is the main composition with the content of $95.5 \%$. The index tests were performed on the saline clay samples at different salt contents according to the American Society for Testing and Materials (ASTM) standard.

The test was performed to illustrate the effect of salt content on index properties of saline clay to explain the strength development in cement admixed saline clay.

The role of salt content and ash content on the strength development is investigated based on the unconfined compression test results. The water contents of the samples with different salt contents were adjusted to the range of liquidity indices $\left(I_{L}\right)$ i.e., 1.0, 1.5, and 2.0.

The liquidity index was used in this investigation as an indicator to refer the initial water content of the clay in relation to plasticity characteristics before cement is admixed as has

234 been done by Horpibulsuk et al. (2003, 2011a and b) and Miura et al. (2001). This intentional 235 increase in water content is to simulate water content increase, taking place in wet method of dispensing cement admixture in deep mixing. The clay samples with their water content, 237 corresponding to the above levels of $I_{L}$ were thoroughly mixed with the blended cements 238 (PC+FA and PC+BA). Cement content, $C_{i}$, varied from 0 to $30 \%$, which is commonly used 
239 for the improvement of high water content clay (Horpibulsuk et al., 2003 and 2011a and b).

240 FA and BA contents, $a$, varied from 0 to $60 \%$ by weight of cement. The mixing time was

241 arbitrarily fixed at $10 \mathrm{~min}$ as recommended by Miura et al. (2001); and Horpibulsuk et al.

242 (2003). Such a uniform paste was transferred to cylindrical containers of $50 \mathrm{~mm}$ diameter and

$243100 \mathrm{~mm}$ height, taking care to prevent any air entrapment. After 24 hours, the cylindrical

244 samples were dismantled. All the cylindrical samples were wrapped in vinyl bags and stored

245 in a humidity room of constant temperature $\left(20 \pm 2^{\circ} \mathrm{C}\right)$ until lapse of different curing times as

246 planned. Unconfined compression (UC) tests were run on samples after 7, 14, 28, 60 and 90

247 days of curing. The rate of vertical displacement in UC tests was $1 \mathrm{~mm} / \mathrm{min}$.

248 To examine the possibility of the clay-water/cement ratio hypothesis, the capability of

249 the $w_{c} / C$ as a prime parameter in analyzing the stress-strain response and strength

250 development in saline clay must be proved. The unconfined compression (UC) tests on the

251 samples having the same $w_{c} / C$ for different water contents were carried out. The $w_{c} / C$ values

252 of 3, 5 and 10 at 28 days of curing were considered. The role of ash as dispersing material on

253 the growth of cementitious products was illustrated by the thermogravimetic (TG) analysis.

254 The blended cement admixed samples were broken from the center into small fragments. The

255 samples were frozen at $-195^{\circ} \mathrm{C}$ by immersion in liquid nitrogen for 5 minutes and evacuated

256 at a pressure of $0.5 \mathrm{~Pa}$ at $-40^{\circ} \mathrm{C}$ for 5 days (Horpibulsuk et al., 2009 and $2010 \mathrm{~b}$ ). Prior to TG

257 testing, the dried samples were ground in a ball mill and sieved through 100 mesh $(150 \mu \mathrm{m})$.

258 Approximately $10-20 \mathrm{mg}$ of the sample was taken for the analysis. The heat rate was

259 maintained at $10^{\circ} \mathrm{C} / \mathrm{min}$ and the sample was heated up to $1,000^{\circ} \mathrm{C}$. When heating the samples

260 at temperature between 450 and $580^{\circ} \mathrm{C}, \mathrm{Ca}(\mathrm{OH})_{2}$ is decomposed into calcium oxide $(\mathrm{CaO})$

261 and water (Midgley, 1979; El-Jazairi and Illston, 1977 and 1980; and Wang et al., 2004) as in

262 Eq. (2).

$263 \mathrm{Ca}(\mathrm{OH})_{2} \quad$----------------> $\mathrm{CaO}+\mathrm{H}_{2} \mathrm{O}$ 
Due to the heat, the water is lost, leading to the decrease in overall weight. The amount of $\mathrm{Ca}(\mathrm{OH})_{2}$ can be approximated from this lost water by Equation (2), which is 4.11 times the amount of lost water (El-Jazairi and Illston, 1977 and 1980). The change of the cementitious products (hydrated calcium silicates, hydrated calcium aluminates and hydrated calcium aluminium silicates) can be expressed by the change of $\mathrm{Ca}(\mathrm{OH})_{2}$ because they are the hydration products. Horpibulsuk et al. (2009, 2010b and 2011a and b) have successfully used this technique to approximate the $\mathrm{Ca}(\mathrm{OH})_{2}$ of the cement admixed clay for explaining the growth of cementitious products and strength development.

Finally, a generalized strength prediction equation for the blended cement admixed saline clay for different salt contents is suggested based on the clay-water/cement ratio hypothesis. It is a very useful tool for mix design. The proposed equation was verified by the separate test results of the BA blended cement admixed saline clay for different water contents $\left(w_{c}=43\right.$ to $\left.62 \%\right)$, cement contents $(C=10$ to $30 \%)$ and ash contents $(a=10,15$ and $25 \%)$.

\section{TEST RESULTS}

\subsection{Strength Development in Cement Admixed Saline Clay}

Figure 3 shows the influence of salt content on the index properties of the saline clay samples. As the salt content increases, both liquid limit and plastic limit decrease; hence the decrease in plasticity index. The decrease in liquid limit is due to the reduction in thickness of diffusion double layer. Even with the change in liquid limit and plastic limit, the relationship between plasticity index, $I_{p}$ and liquid limit, $w_{L}$ of all saline clay samples still lies above Aline as shown in Figure 4. Since $I_{p}$ and $w_{L}$ relation is unique for all saline clay samples, either $I_{p}$ or $w_{L}$ can be used to explain the change in their intrinsic engineering properties with salt content. In this study, the liquid limit, which is widely used in correlating index properties to 
intrinsic properties (Nagaraj et al., 1998; and Burland, 1990; and Liu and Carter 1999; and Horpibulsuk et al., 2007; and Horpibulsuk et al., 2011c), is taken. shown in Figure 5. As the salt content increases, the strength decreases. The presence of the salt affects the generalized stress state $e / e_{L}$ of the saline clay. For a particular water content, the generalized stress state $e / e_{L}$ decreases with the salt content due to the decrease in liquid limit; therefore, the effective stress (inter-particle attraction) of cement admixed saline clay decreases. This causes the decrease in strength of cement admixed saline clay.

Figure 6 shows the typical stress-strain relationships in unconfined compression tests of saline clay samples for different initial water contents and cement contents but the same $w_{c} / C$ values of 3,5 , and 10 and salt content of $1.3 \%$. It is noted that the $w_{c} / C$ is the prime parameter governing the strength development when the salt content is the same. As the $w_{c} / C$ decreases, the strength increases due to the stronger cementation bond. The similar stressstrain behavior of all the admixed samples, having the same $w_{c} / C$ values, is figured out. It is 304 concluded from these results that the strength of cement admixed saline clay is controlled by 305 both the clay-water/cement ratio and the salt content.

307 Figure 4: Relationship between $I_{p}$ and $w_{L}$ of the saline clay for various salt contents.

308 Figure 5: Strength development with time of the saline clay for various salt contents.

309 Figure 6: Role of wc/C on the strength development in the saline clay for different water 310 contents and cement contents. 


\subsection{Role of Fly Ash on Strength Development}

The typical strength development with ash content for the FA blended cement admixed saline clay is shown in Figure 7, which is for 53\% water, 20\% cement and 28 days of curing. Both the strength and unit weight increase with fly ash content and achieve the peak values at $a=25 \%$. They decrease gradually with the ash content when $a>25 \%$. The fly ashes in excess of $25 \%$ possibly surround the cement grains and obstruct the interaction between water and cement grains. Consequently, the cementatious products decrease and hence the reduction in strength when $a>25 \%$. This characteristic is the same as that of the FA and BA blended cement admixed Bangkok clay reported by Horpibulsuk et al. (2011a). The optimal ash content is $25 \%$ and independent of cement content because the ash content is determined in proportion to the cement content.

The role of ash on the strength development is illustrated by the growth of cementitious products as shown in Table 3. It shows the amount of $\mathrm{Ca}(\mathrm{OH})_{2}$ for the FA blended cement admixed saline clay at $53 \%$ water for different cement contents and fly ash contents. For the range of ash content tested $(a \leq 25 \%)$, the amount of $\mathrm{Ca}(\mathrm{OH})_{2}$ for all the blended cement admixed samples is higher than that of the cement admixed sample (without fly ash). This higher amount of $\mathrm{Ca}(\mathrm{OH})_{2}$ is associated with the higher strength for the blended cement admixed clay. In contrast, for fly ash concrete, the strength increase due to pozzolanic reaction is associated with the reduction in $\mathrm{Ca}(\mathrm{OH})_{2}$ (Chindaprasirt et al., 2004 and 2006; and Sinsiri et al., 2006). This result confirms that the pozzolanic reaction is minimal for the blended cement admixed clay. The contribution of the ash to the strength development is mainly dispersing effect.

Figure 7: Relationship between strength and unit weight versus fly ash content. 
338 Table 3: $\mathrm{Ca}(\mathrm{OH})_{2}$ of the FA blended cement admixed saline clay for different cement contents 339 and fly ash contents at 28 days of curing time.

340

Based on Eq.(1), the analysis of strength development for the effective dispersing range ( $a \leq 25 \%)$ is performed and shown in Figure 8 and 9. The generalized two-dimensional $q_{u}-w_{c} / C$ plots for the FA and BA blended cement admixed saline clay with $1.3 \%$ salt at different curing times are shown. Similarly, the role of salt content on the strength development is illustrated in Figure 10 for 7 and 28 days of curing. It is clear that the claywater/cement ratio hypothesis can be applied to cement admixed saline clay with a wide range of salt content. The variation of parameter $A$ is marked and is dependent on curing time and salt content. The strength of cement admixed saline clay decreases with salt content; therefore, the $A$-value decreases as the salt content increases. The values of $B$ and $k$ are practically identical for both the blended FA and BA admixed saline clay and irrespective of water content, cement content, ash content and curing time. The variations of parameters $B$ and $k$ are very small, which are between 1.25 and 1.27 and 0.74 and 0.78 for both the FA and BA blended cement admixed saline clay. On the contrary, the $k$-value of the fly ash concrete increases significantly with curing time (Papadakis and Tsimas, 2002). It is concluded from the present work and the previous works (Horpibulsuk et al., 2009; 2011a and b) that the dispersing effect is independent of salt content and shape and grain size of the ashes. The $B$ and $k$-values can be taken as 1.27 and 0.75 for non- to low-swelling clays.

Figure 8: Relationship between strength and clay-water/cement ratio for FA blended cement admixed saline clay.

Figure 9: Relationship between strength and clay-water/cement ratio for BA blended cement admixed saline clay. 
363 Figure 10: Relationship between strength and clay-water/cement ratio of FA blended cement 364 admixed saline clay for various salt contents.

365

366

$$
\frac{q_{D}}{q_{28}}=0.099+0.281 \ln D
$$

where $q_{D}$ is the strength after $D$ days of curing, $q_{28}$ is the 28 day-strength and $D$ is the curing

From Eq.(1), at a particular curing time, the strength ratio at different claywater/cement ratio is proposed as follows:

$$
\frac{q_{\left(w_{c} / C\right)_{1}}}{q_{\left(w_{c} / C\right)_{2}}}=\left[\frac{\left(w_{c} / C\right)_{2}}{\left(w_{c} / C\right)_{1}}\right]^{1.27}
$$

where $q_{\left(w_{c} / C\right)_{1}}$ is the strength to be estimated at clay-water/cement ratio of $\left(w_{c} / C\right)_{1}$ and $q_{\left(w_{c} / C\right)_{2}}$ is the strength value at clay-water/cement ratio of $\left(w_{c} / C\right)_{2}$. From the above equation, it is possible to assess the strength at any other clay-water/cement ratio (clay-water content, cement content and fly ash content).

\subsection{Strength Development with Curing Time}

The typical strength development with curing time is shown in Figures 11 and 12 for the FA and BA blended cement admixed saline clay with $1.3 \%$ salt, respectively. It is noted that strength development with curing time (days) in natural logarithmic scale can be expressed as linear variation. It is evident that at a particular $w_{c} / C$, the strength development with time is controlled by the $A$-value only because the $B$ - and $k$-values for all practical purposes can be regarded as constant. Even though the $A$-values are different for different salt contents, the rate of strength development with time is identical because the cementitious products influence the rate predominantly. The generalized strength development for the FA and BA blended cement admixed saline clay is presented in the form (vide Figure 13):

$$
\text { time (days). This generalized strength development is close to that proposed for cement }
$$


admixed clays (with and without ashes) (Horpibulsuk et al., 2003; and 2011a and b). It accounts for the effects of clay water content, cement content and ash content.

389

Figure 11: Strength development with time for the FA blended cement admixed saline clay.

391 Figure 12: Strength development with time for the BA blended cement admixed saline clay.

392 Figure 13: Generalized strength development for the FA and BA blended cement admixed 393 saline clay.

394

395

\section{INTERRELATIONSHIP AMONG STRENGTH, CLAY-WATER/CEMENT RATIO}

\section{AND CURING TIME}

Because the clay-water/cement ratio hypothesis is valid for cement admixed saline clay, the generalized strength equation can be developed in the same way as for the original one (Horpibulsuk et al., 2011a). The generalized interrelationship among strength, curing time

401 and $w_{c} / C$ for assessing strength development of the blended cement admixed saline clay in 402 which the $w_{c} / C$ ranges from 1 to 6 is expressed by combination of Equations (3) and (4).

$403\left\{\frac{q_{\left(w_{c} / C\right)_{D}}}{q_{\left(w_{c} / C\right)_{28}}}\right\}=\left[\frac{\left(w_{c} / C\right)_{28}}{\left(w_{c} / C\right)_{D}}\right]^{1.27}(0.099+0.281 \ln D)$

404 where $q_{\left(w_{c} / C\right)_{D}}$ is the strength of the blended cement admixed saline clay to be estimated at 405 clay-water/cement ratio of $\left(w_{c} / C\right)_{D}$ after $D$ days of curing and $\left.q_{\left(w_{c}\right.} / C\right)_{28}$ is the strength of the 406 blended cement admixed saline clay at clay-water/cement ratio of $\left(w_{c} / C\right)$ after 28 days of 407 curing and

$408 C=C_{i}(1+0.75 a)$ 
In this development of the interrelationship, the $k$ value of 0.75 is considered for

$410 a \leq 25 \%$. Using Eq. (5), the assessment of the strength development in the BA blended

411 cement admixed saline clay with $1.3 \%$ salt is presented in Table 4 as an example. The 28-day

412 strength of the sample made up at $w_{c}=43 \%, C=20 \%$ and $a=10 \%$ was taken as a reference.

413 The error from the prediction is acceptable for engineering practice with the mean absolute

414 percent error less than $8.2 \%$. This reinforces the applicability of the proposed relationship.

415 The expression proposed is simple within the framework of Abrams' law and requires the

416 strength data of a trial mix. Based on the previous researches (Horpibulsuk et al., 2011a and

417 b) and the present work, it is concluded that equation (5) is valid for low-swelling clays with a

418 wide range of salt content. The $B$ - and $k$-values can be taken as 1.27 and 0.75 , respectively.

419 The equation requires only a laboratory strength value of the cement admixed clay (with or

420 without fly ash and biomass ash) for a particular curing time and mixing condition (water

421 content and cement content).

422 An addition of $25 \%$ ash is recommended for an economic mix design. By substituting $423 a=25 \%$ in Eq.(6), the economic input of cement for the blended cement admixed clay in 424 terms of the total equivalent cement is $C_{i}=0.842 C$. This recommended mix design can save 425 on the input of cement up to $15.8 \%\left[\left(\frac{1-0.842}{1}\right) \times 100 \%\right]$.

427 Table 4: Strength prediction of the BA blended cement admixed Bangkok clay. 


\section{CONCLUSIONS}

This paper deals with the analysis and assessment of strength development in the blended cement admixed saline clay. The clay-water/cement ratio hypothesis is extended for this study. The following conclusions can be advanced from this study.

1. The presence of salt content affects the index properties of saline clay. The liquid limit decreases as salt content increases due to the decrease in the thickness of diffusion double layer. For a particular water content, the generalized stress state $e / e_{L}$ increases as the salt content increases. This causes the reduction in the effective stress (inter-particle attraction) and shear strength of the saline clay.

2. The strength development in cement admixed saline clay is dependent upon the salt content and clay-water/cement ratio. The clay-water/cement ratio hypothesis is applicable for analyzing and assessing the strength development in cement admixed saline clay. For the cement admixed saline clay samples with different salt contents but the same clay-water/cement ratio, the samples with lower salt content exhibits higher strength due to the lower generalized stress state, $e / e_{L}$.

3. Due to the dispersing effect, fly ash and biomass can be used to reduce the input of cement. The $25 \%$ ash content is the most effective amount and can save cement up to $15.8 \%$ for achieving the same strength. The strength test results and thermogravimetric analysis show that this ash content yields highest cementitious products and strength. This dispersion increases the reactive surface for hydration and hence cementitious products and strength.

4. Based on the present work, a generalized strength equation for blended cement admixed non- to low swelling clays is suggested. The $B$ - and $k$-values can be taken as 1.27 and 0.75 for all curing times. The equation facilitates the determination of proper 
quantity of blended cement to be admixed for different in-situ and field mixing water contents. The formulation of the proposed relationship is on sound principle.

\section{ACKNOWLEDGEMENT}

The authors would like to acknowledge the financial support and facilities provided from the Suranaree University of Technology.

\section{REFERENCES}

Abrams DA. Design of Concrete Mixtures. In: Structural Materials Research Laboratory, Lewis Institute, Chicago, Bulletin 1; 1918. 20p.

Burland, J.B., 1990. On the compressibility and shear strength of natural clays. Geotechnique 40 (3), 329-378.

Chindaprasirt, P., Homwuttiwong, S. and Sirivivatnanon, V., 2004. Influence of fly ash fineness on strength, drying shrinkage and sulfate resistance of blended cement mortar. Cement and Concrete Research 34, 1087-1092.

Chindaprasirt, P., Jaturapitakkul, C. and Sinsiri, T., 2006. Effect of fly ash fineness on microstructure development of blended cement plates. Construction and Building Materials 21, 1534-1541.

El-Jazairi, B. and Illston, J.M., 1977. A simultaneous semi-isothermal method of thermogravimetry and derivative thermogravimetry, and its application to cement plates. Cement and Concrete Research 7, 247-258.

El-Jazairi, B. and Illston, J.M., 1980. The hydration of cement plate using the semi-isothermal method of thermogravimetry. Cement and Concrete Research 10, 361-366.

Horpibulsuk, S. and Miura N., 2001. A new approach for studying behavior of cement stabilized clays. Proceedings of 15th International Conference on Soil Mechanics and Geotechnical Engineering (ISSMGE). Istanbul, Turkey, vol. 3, pp. 1759-1762.

Horpibulsuk, S. and Raksachon, Y., 2010. Fly ash as a dispersing material in cement stabilization. Proceedings of Geo-Shanghai 2010. China, pp. 137-142.

Horpibulsuk S., Bergado, D.T. and Lorenzo, G.A., 2004a. Compressibility of cement admixed clays at high water content. Geotechnique 54 (2), 151-154. 
487

488

489

490

491

492

493

494

495

496

497

498

499

500

501

502

503

504

505

506

507

508

509

510

511

512

513

514

515

516

517

518

Horpibulsuk, S., Miura, N. and Bergado D.T., 2004b. Undrained shear behavior of cement admixed clay at high water content. Journal of Geotechnical and Geoenvironmental Engineering, ASCE 130 (10), 1096-1105.

Horpibulsuk, S., Miura, N., Nagaraj, T.S., 2003. Assessment of strength development in cement-admixed high water content clays with Abrams' law as a basis. Geotechnique 53 (4), 439-444.

Horpibulsuk, S, Miura, N. and Nagaraj, T.S., 2005. Clay-water/cement ratio identity of cement admixed soft clay. Journal of Geotechnical and Geoenvironmental Engineering, ASCE 131 (2), 187-192.

Horpibulsuk, S., Rachan R. and Raksachon Y., 2009. Role of fly ash on strength and microstructure development in blended cement stabilized silty clay. Soils and Foundations 49 (1), 85-98.

Horpibulsuk, S., Rachan, R. and Suddeepong, A., 2011a. Assessment of strength development in blended cement admixed Bangkok clay. Construction and Building Materials 25 (4), 1521-1531.

Horpibulsuk, S., Liu M.D., Liyanapathirana, D.S. and Suebsuk, J., 2010a. Behavior of cemented clay simulated via the theoretical framework of the Structured Cam Clay model. Computers and Geotechnics 37, 1-9.

Horpibulsuk, S., Rachan, R., Suddeepong, A. and Chinkulkijniwat, A., 2011b. Strength development in cement admixed Bangkok clay: laboratory and field investigations. Soils and Foundations (In press).

Horpibulsuk, S., Shibuya, S., Fuenkajorn, K. and Katkan, W., 2007. Assessment of engineering properties of Bangkok clay. Canadian Geotechnical Journal 44 (2), 173187.

Horpibulsuk, S., Yangsukaseam, N., Chinkulkijniwat, A. and Du, Y.J., 2011c. Physical, compressibility and permeability characteristics of Bangkok clay compared with those of kaolinitic and montmorillonitic soils. Applied Clay Science (In press).

Horpibulsuk, S., Rachan, R., Raksachon, Y., Suddepong, A. and Chinkulkijniwat, A. 2010b. Analysis of strength development in cement-stabilized silty clay based on microstructural considerations. Construction and Building Materials 24, 2011-2021.

Kamon, M. and Bergado, D.T., 1992. Ground improvement techniques. Proceedings of 9th Asian Regional Conference on Soil Mechanics and Foundation Engineering, 526-546. 
Kawasaki, T., Niina, A., Saitoh, S., Suzuki, Y. and Honjo, Y., 1981. Deep mixing method using cement hardening agent. Proceedings of $10^{\text {th }}$ International Conference on Soil Mechanics and Foundation Engineering. Stockholm, 721-724.

Liu M. D. and Carter J. P. (1999), "Virgin compression of structured soils", Géotechnique, Vol. 49(1), pp.43-57.

Midgley, H.G., 1979. The determination of calcium hydroxide in set Portland cements. Cement and Concrete Research 9, 77-82.

Miura, N., Horpibulsuk, S. and Nagaraj, T.S., 2001. Engineering behavior of cement stabilized clay at high water content. Soils and Foundations 41 (5), 33-45.

Nagaraj, T.S., Pandian, N.S. and Narasimha Raju, P.S.R., 1998. Compressibility behavior of soft cemented soils. Geotechnique 48 (2), 281-287.

Papadakis, V.G. and Tsimas, S., 2002. Supplementary cementing materials in concrete Part I: efficiency and design. Cement and Concrete Research 32, 1525-1532.

Prakash, K. and Sridharan, A. 2004. Free swell ratio and clay mineralogy of fine-grained soils. Geotechnical Testing Journal, ASTM 27 (2), 220-225.

Sinsiri, T., Jaturapitakkul, C. and Chindaprasirt, P., 2006. Influence of fly ash fineness on calcium hydroxide in blended cement paste. Proceedings of Technology and Innovation for Sustainable Development Conference (TISD2006). Khon Kaen, Thailand.

Suebsuk, J., Horpibulsuk, S. and Liu, M.D., 2010. Modified Structured Cam Clay: A constitutive model for destructured, naturally structured and artificially structured clays. Computers and Geotechnics 37, 956-968.

Suebsuk, J., Horpibulsuk, S. and Liu, M.D., 2011. A critical state model for overconsolidated structured clays. Computers and Geotechnics (in press).

Terashi, M., Tanaka, H. and Okumura, T., 1979. Engineering properties of lime treated marine soils and DMM. Proceedings of $6^{\text {th }}$ Asian Regional Conference on Soil Mechanics and Foundation Engineering, 191-194.

US Salinity Laboratory Staff. 1995. Diagnosis and improvement of saline and alkaline soils. USDA Handbook No.60, Washington DC.

Wang, K.S, Lin, K.L., Lee, T.Y. and Tzeng, B.Y., 2004. The hydration characteristics when $\mathrm{C}_{2} \mathrm{~S}$ is present in MSWI fly ash slag. Cement and Concrete Research 26, 323-330.

Yavaniyama, A., Lertsirivorakul, R. and Sriboonruang, V. 2005, Effect of land use management on groundwater and soil salinization in northeast Thailand. Workshop on Management of Tropical Sandy Soils for Sustainable Agriculture, Khon Kaen, Thailand. 


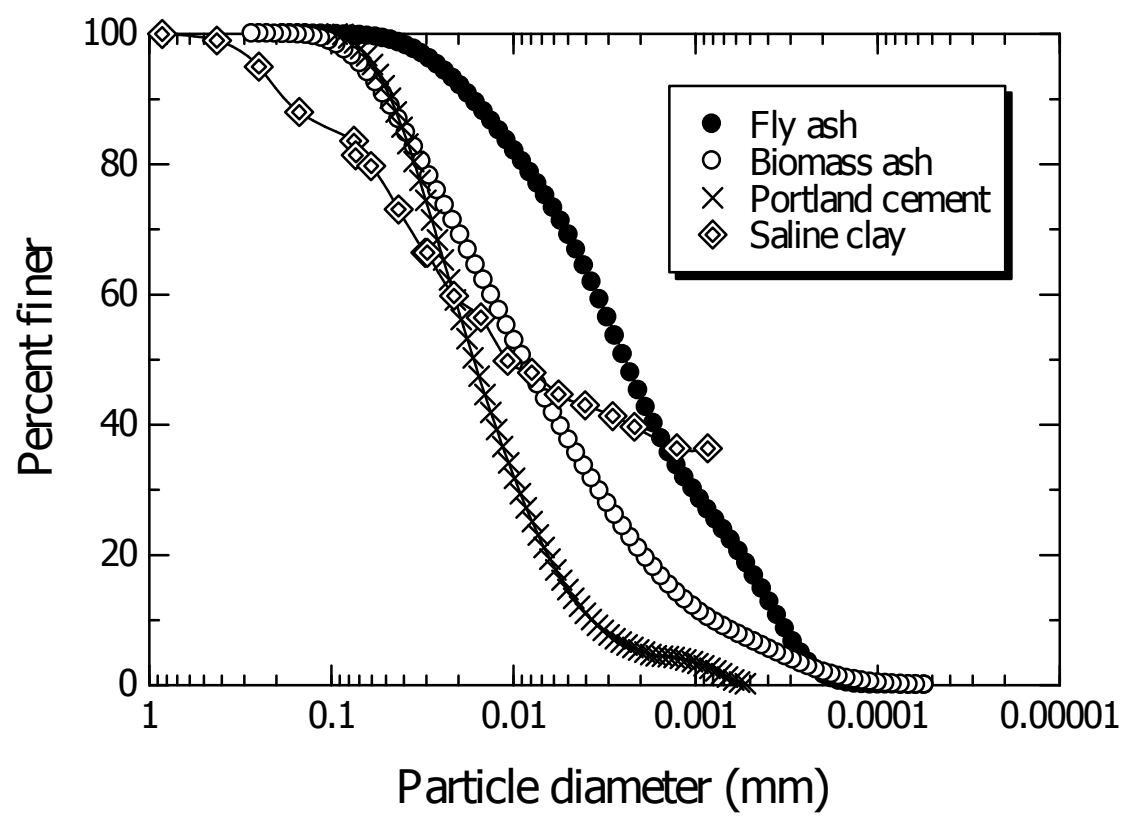

Figure 1: Grain size distribution of saline clay, fly ash, biomass ash and Portland cement. 
576

577

578

579

580

581

582

583

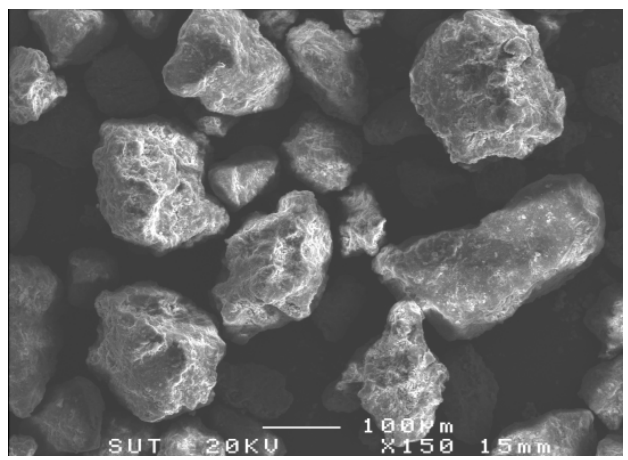

(a)

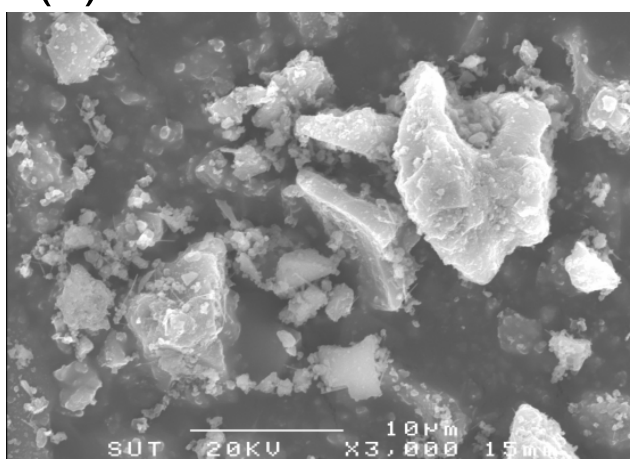

(c)

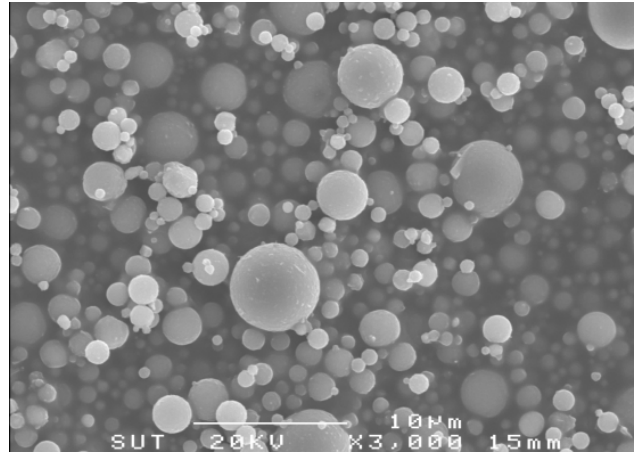

(b)

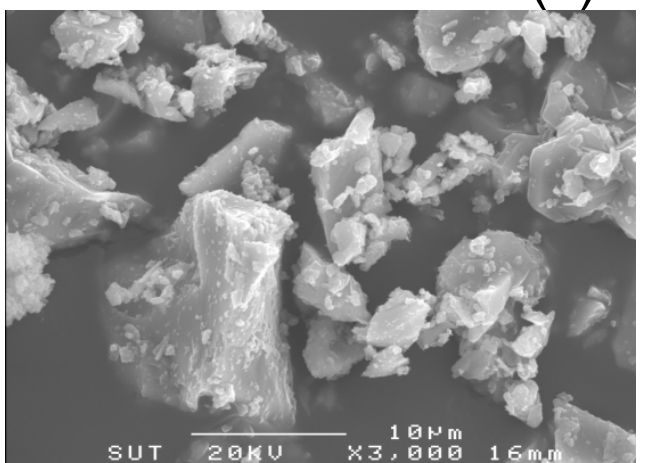

(d)

Figure 2: SEM photos of saline clay, fly ash, biomass ash and Portland cement Type I.

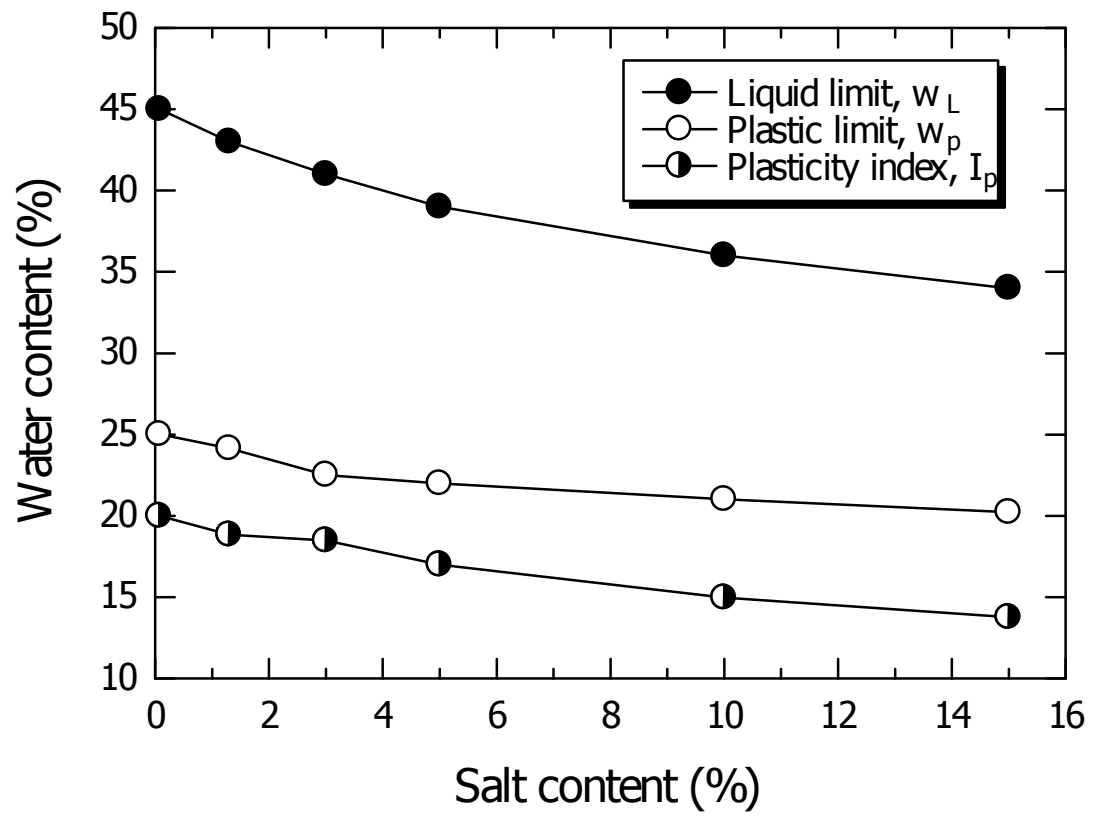

Figure 3: Index properties of saline clay for various salt contents. 


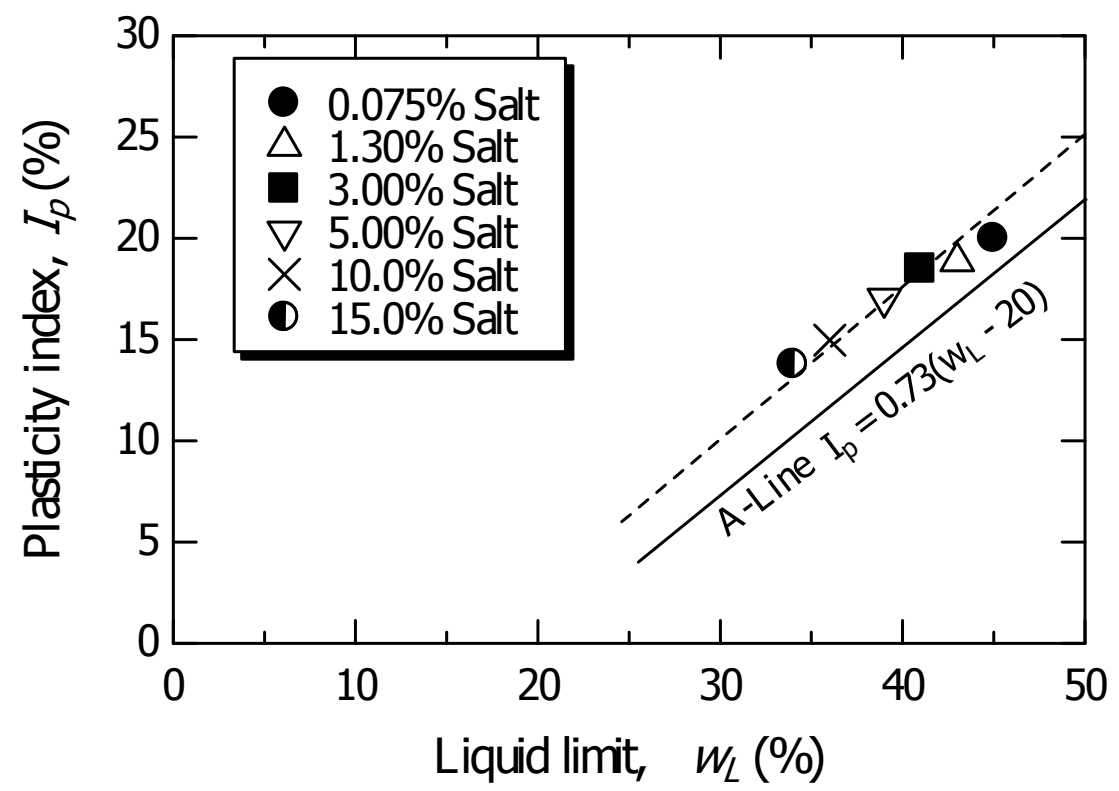

Figure 4: Relationship between $I_{p}$ and $w_{L}$ of the saline clay for various salt contents.

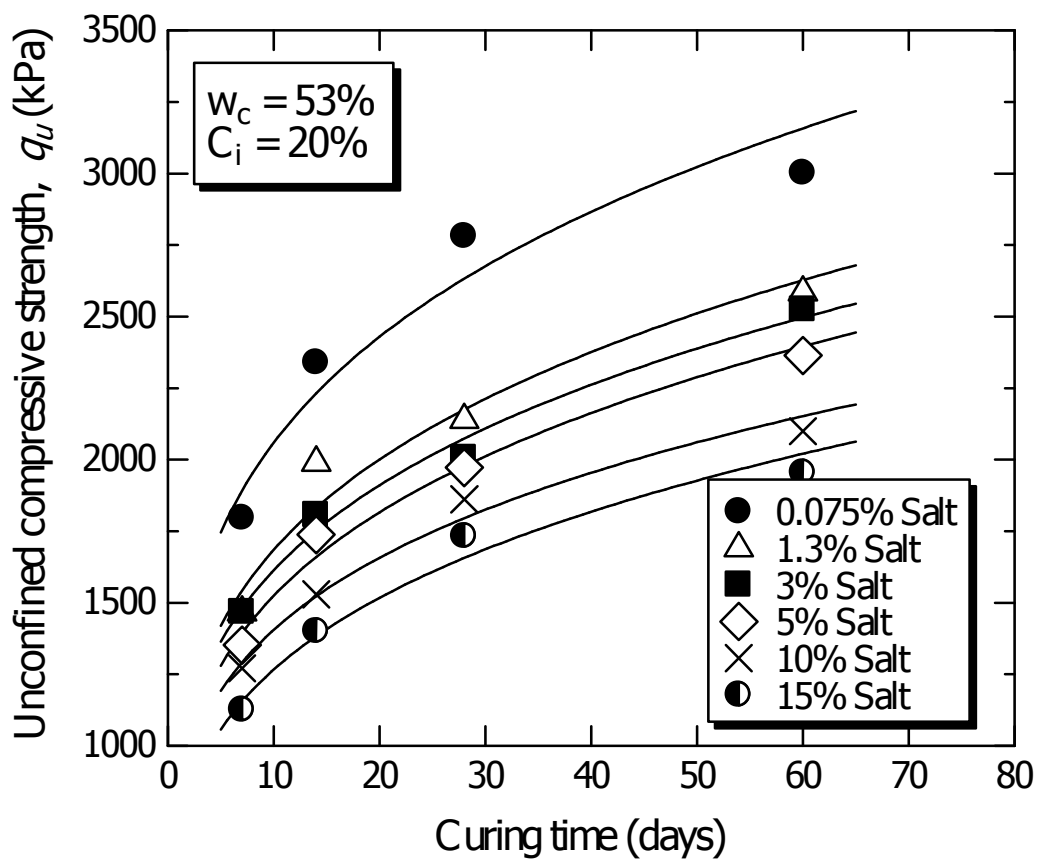




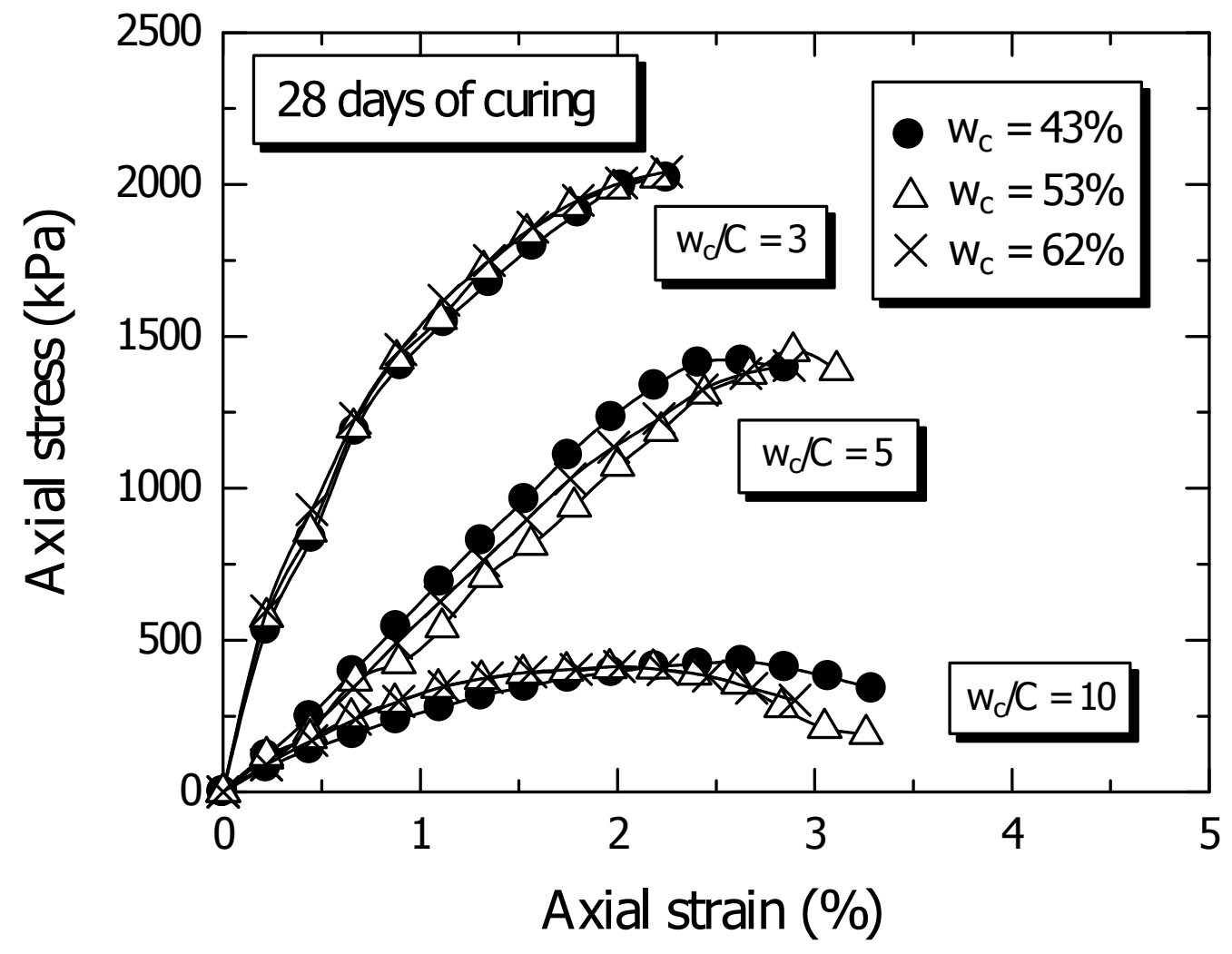
contents and cement contents. 

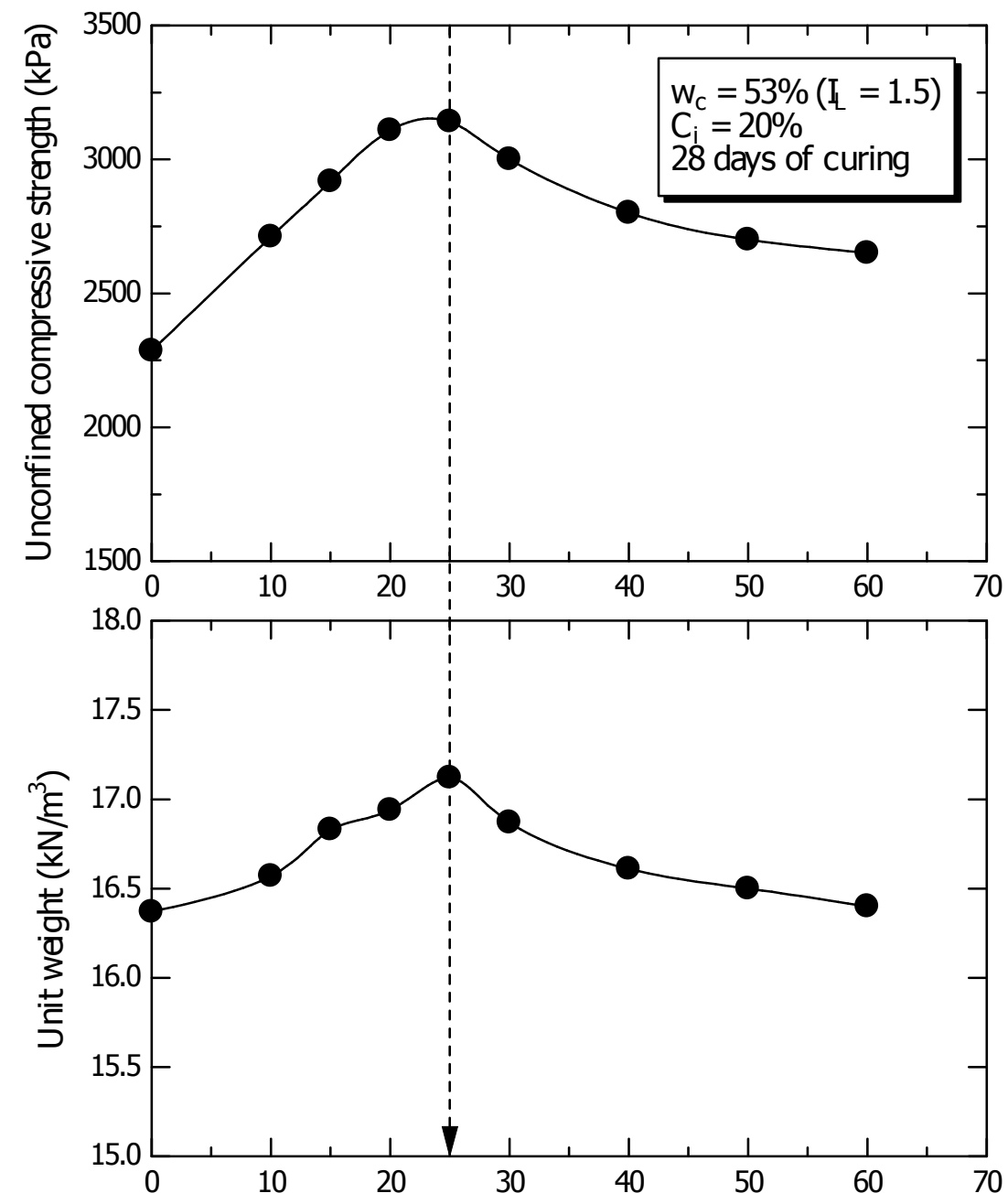

Fly ash content, $a(\%)$

601

602

603
Figure 7: Relationship between strength and unit weight versus fly ash content. 


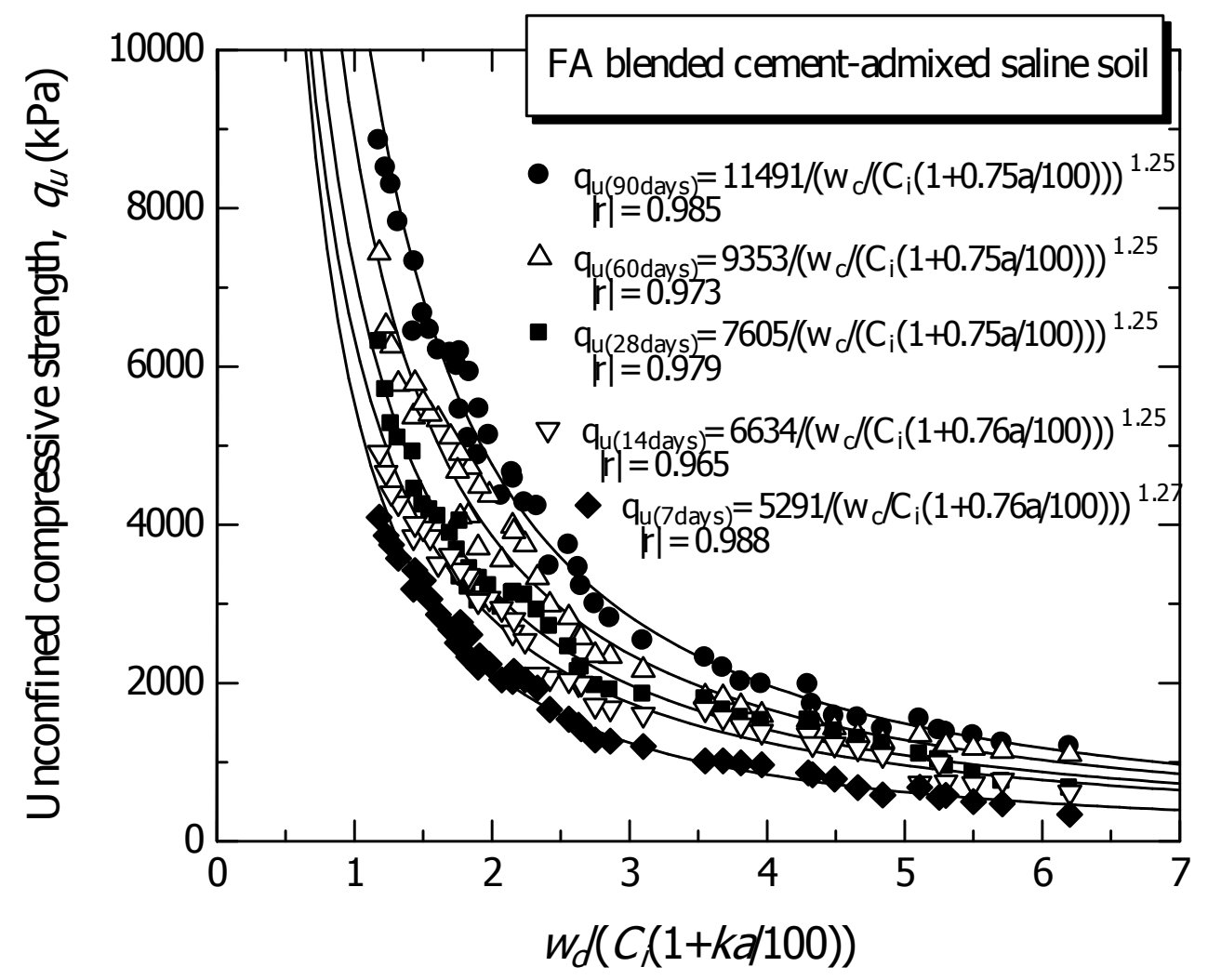

604

605

606

607

608
Figure 8: Relationship between strength and clay-water/cement ratio for FA blended cement admixed saline clay. 


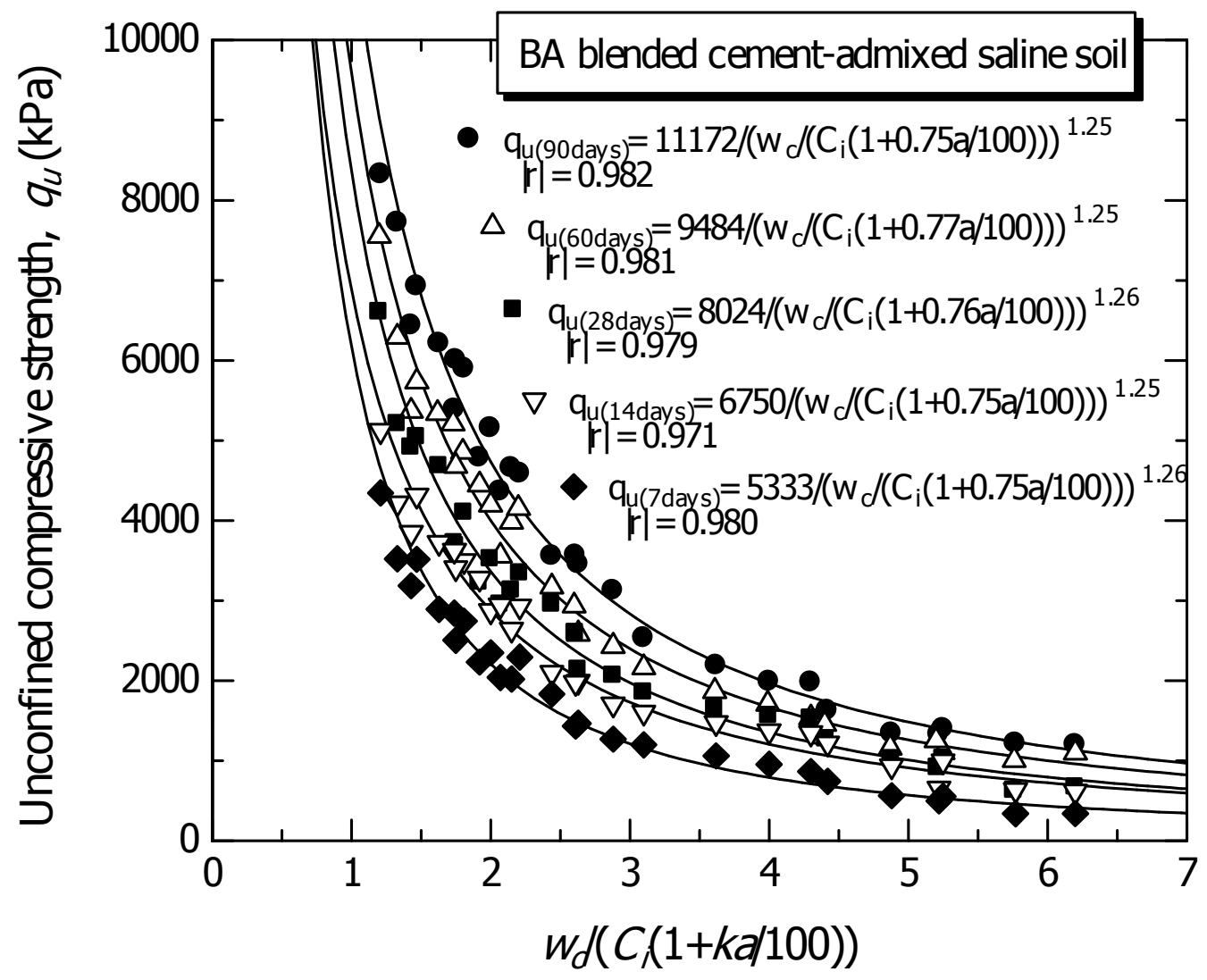

609

610

611

612

613
Figure 9: Relationship between strength and clay-water/cement ratio for BA blended cement admixed saline clay. 


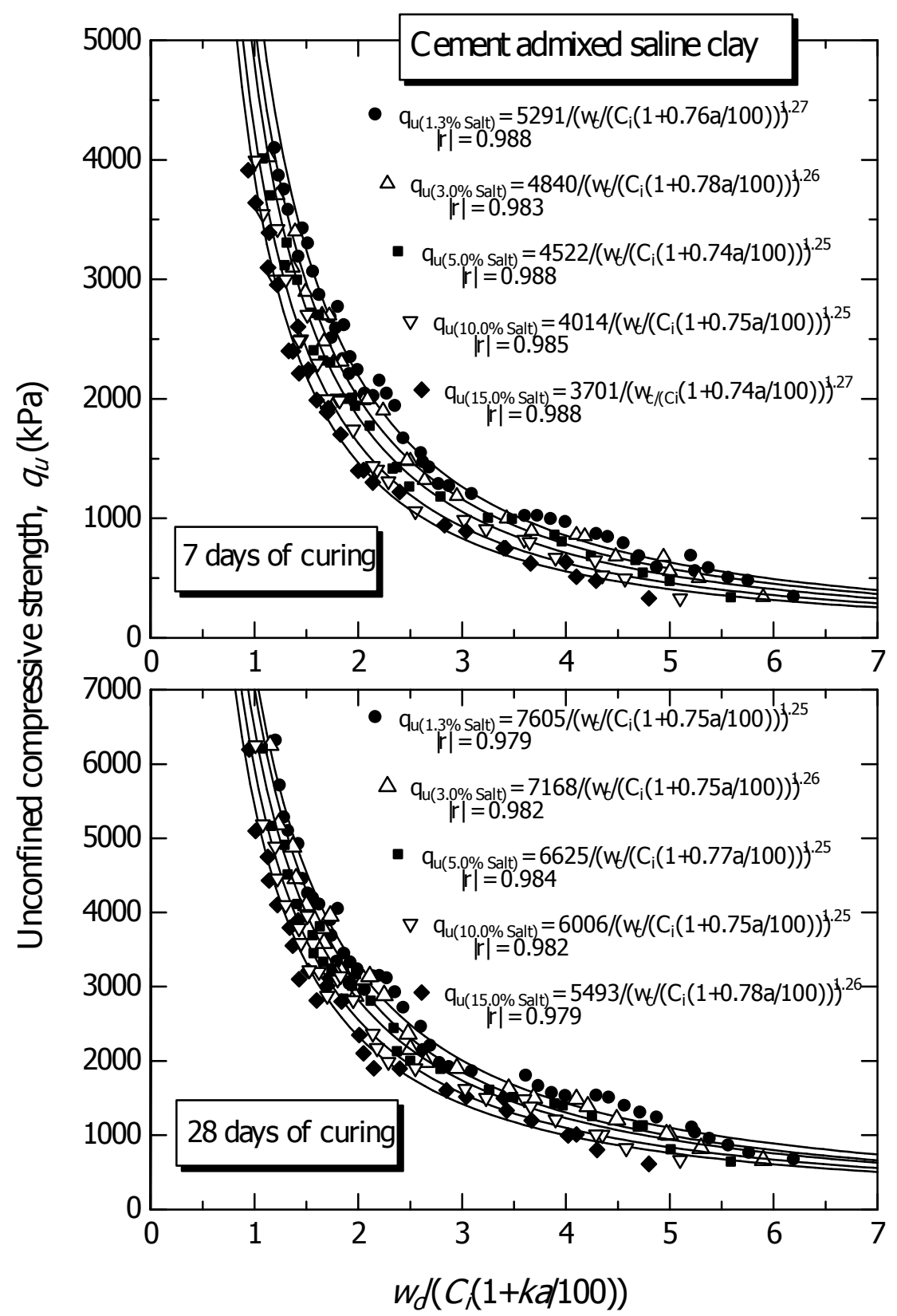

614

615

616

Figure 10: Relationship between strength and clay-water/cement ratio of FA blended cement admixed saline clay for various salt contents. 


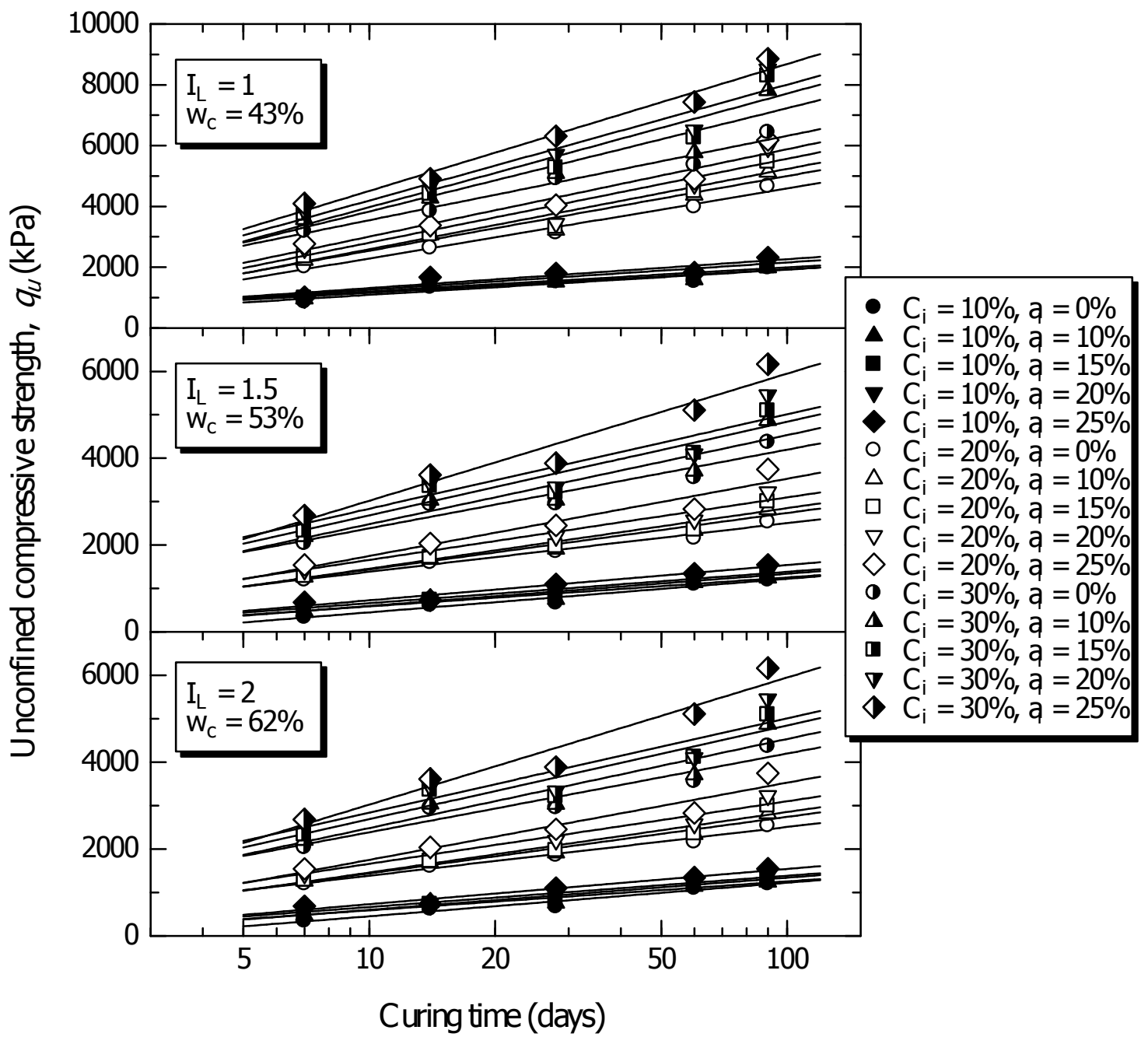

617

Figure 11: Strength development with time for the FA blended cement admixed saline clay. 


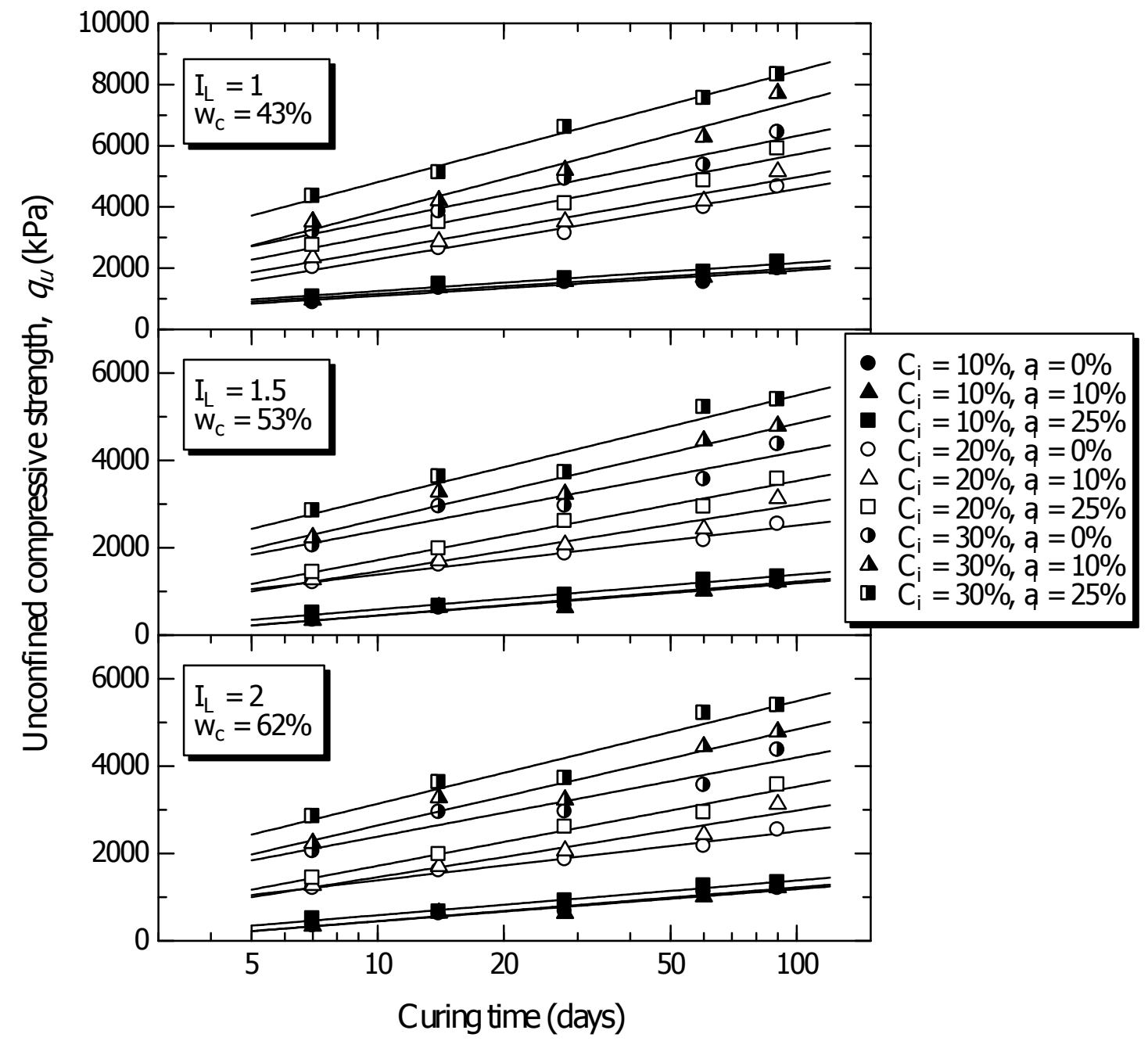




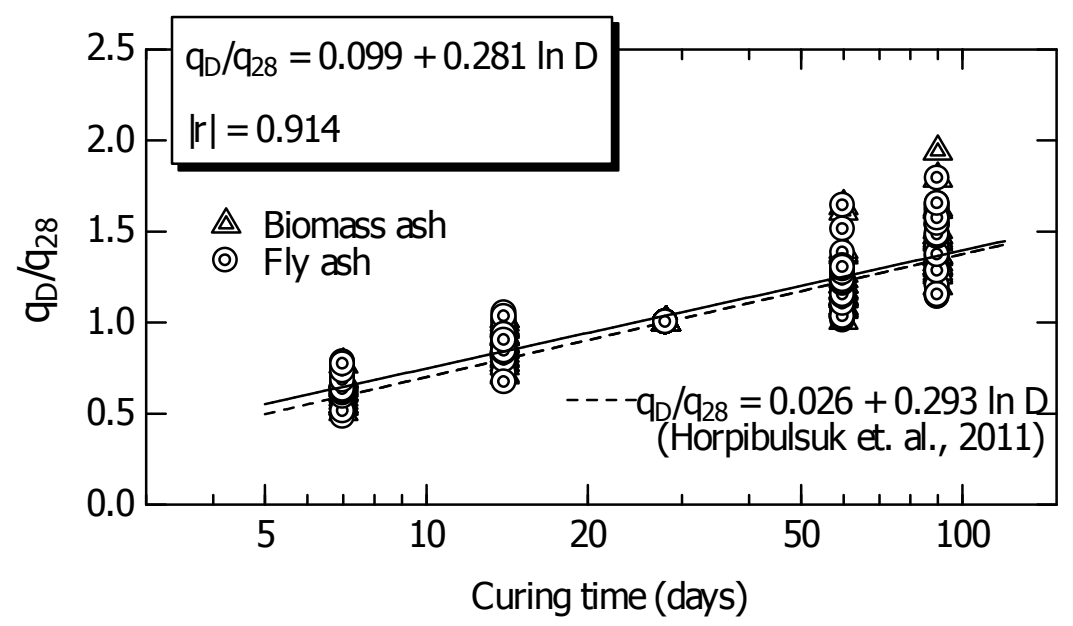

638

639

640

641

642

643

644

645

646

647

648

649

650

651

652

653

654

655

656

Figure 13: Generalized strength development for the FA and BA blended cement admixed saline clay. 


\section{Figure Captions}

659 Figure 1: Grain size distribution curves of Bangkok clay, PC, FA, and BA.

660 Figure 2: SEM photos of Bangkok clay, cement, FA, and BA.

661 Figure 3: Strength development with fly ash content for different water contents.

662 Figure 4: Strength development with fly ash content for different cement contents.

663 Figure 5: Analysis of strength development in the FA blended cement admixed Bangkok clay

664 using the clay-water/cement ratio hypothesis.

665 Figure 6: Analysis of strength development in the BA blended cement admixed Bangkok clay

666 using the clay-water/cement ratio hypothesis

667 Figure 7: Compression behavior of the FA blended cement admixed Bangkok clay samples,

668 having the same $w_{c} / C$.

669 Figure 8: Stress-strain relationship of the FA blended cement admixed Bangkok clay samples,

670 having the same $w_{c} / C$ under unconfined compression test.

671 Figure 9: Strength development in the FA blended cement admixed clay.

672 Figure 10: Strength development in the BA blended cement admixed clay.

673 Figure 11: Generalized strength development for FA and BA blended cement admixed 674 Bangkok clay. 